\title{
Efektivitas Hukum Pencabutan Hak Dipilih terhadap Koruptor Dalam Pemberantasan Korupsi
}

\author{
Baumi Syaibatul Hamdi \\ Program Pascasarjana Fakultas Hukum Universitas Islam Indonesia \\ Jln. Cik Di Tiro No. 1, Yogyakarta, 55223 \\ baumi.syaibatul.hamdi@gmail.com
}

\begin{abstract}
Corruption is an endless problem in Indonesia. Judging from its practice, corruption is often identified with the abuse of authority or power for personal gain. The issues raised in this study are, first, how is the revocation of the rights to be elected in the perspective of laws and regulations? Second, how is the effectiveness of revocation of the rights to be elected in eradicating corruption? This study aims to analyze the effectiveness of the law of revocation of the rights to be elected against corruptors in eradicating corruption. The analysis is described through the statutory approach and conceptual approach. This study concludes, first, revocation of the rights to be elected against corruptors is one of criminal sanctions and an effective effort in eradicating corruption and does not constitute a violation of human rights. Criminal law, human rights law and the Corruption Act provide legitimacy to revoke the rights to be elected against corruptors. Second, the effectiveness of the law on revocation of such rights has a deterrent and prevention effects. Revocation of selected rights has become a necessity for judges to make revocation of chosen rights as a standard imposing sanctions for corruptors in the context of eradicating corruption.
\end{abstract}

Key words: Effectivity; law; revocation of the rights to be elected; corruption eradication

\begin{abstract}
Abstrak
Korupsi merupakan persoalan yang tak ada habisnya di Indonesia. Dilihat dari parakteknya, korupsi sering diidentikkan dengan penyalahgunaan wewenang atau kekuasaan demi keuntungan secara pribadi. Permasalahan yang diangkat dalam penelitian ini, pertama, bagaimana pencabutan hak dipilih dalam perspektif peraturan perundang undangan? Kedua, bagaimana efektivitas pencabutan hak dipilih dalam pemberantasan korupsi? Penelitian ini bertujuan menganalisis efektivitas hukum pencabutan hak dipilih terhadap koruptor dalam pemberantasan korupsi. Analisis dideskripsikan melalui pendekatan peraturan perundang-undangan dan pendekatan konseptual. Penelitian ini menyimpulkan, pertama, pencabutan hak dipilih terhadap koruptor menjadi salah satu sanksi pidana dan upaya yang efektif dalam pemberantasan korupsi dan bukan merupakan pelanggaran HAM. Hukum pidana, hukum HAM dan UU Tipikor memberikan legitimasi untuk dilakukan pencabutan hak dipilih terhadap pelaku koruptor. Kedua, efektifitas hukum pencabutan hak dipilih memberikan efek jera dan juga pencegahan. Pencabutan hak dipilih sudah menjadi keharusan bagi hakim untuk menjadikan pencabutan hak dipilih sebagai standar penjatuhan sanksi bagi para koruptor dalam rangka pemberantasan korupsi.
\end{abstract}

Kata-kata Kunci: Efektivitas; hukum; pencabutan hak dipilih; pemberantasan korupsi 


\section{Pendahuluan}

Persoalan tindak pidana korupsi merupakan persoalan yang tak kunjung ada habisnya di Indonesia. Tindak pidana korupsi seakan-akan menjadi budaya sehingga sangat sulit untuk melakukan pemberantasan apalagi dengan waktu yang singkat. Berbagai upaya dilakukan terhadap pemberantasan tindak pidana korupsi namun masih saja korupsi merajalela. Sehingga mengharapkan good governance, birokrasi yang bersih dari korupsi di Indonesia seakan-akan "bagai pungguk merindukan bulan". Bukan karena pesimisme melainkan karena melihat fakta. Semakin hari semakin banyak pejabat negara yang tersandung kasus korupsi bahkan dengan jumlah yang tidak sedikit. Di sisi lain, penegakan hukum tindak pidana korupsi oleh aparat penegak hukum belum menyadari sepenuhnya tingkat kejahatan tindak pidana korupsi itu sendiri, padahal sejatinya tindak pidana korupsi merupakan extra ordinary crime. Ini dapat dilihat disparitas sanksi pidana yang di jatuhkan terhadap terpidana korupsi, masih ada penjatuhan sanksi pidana yang relatif ringan.

Bukan itu saja, yang paling menarik adalah beberapa kasus tindak pidana korupsi pelakunya yang di tuntut dengan pencabutan hak politik dan hakim menolak dilakukan pencabutan hak politik ${ }^{1}$ pelaku tindak pidana korupsi dengan alasan bahwa pencabutan hak politik adalah pelanggaran hak asasi manusia. Contoh kasus di antaranya adalah mantan anggota Komisi V Dewan Perwakilan Rakyat (DPR) Damayanti Wisnu Putranti, mantan anggota Dewan Perwakilan Rakyat Daerah (DPRD) DKI Jakarta Mohammad Sanusi dan lain-lainnya. Dengan kata lain aparat penegak hukum khususnya hakim juga masih setengah-setengah dalam mengoptimalkan produk hukum yang ada dalam pemberantasan tindak pidana korupsi. Adalah sangat aneh pencabutan hak politik masih dianggap sebagai pelanggaran hak asasi manusia, padahal undang-undang memberikan legitimasi.

\footnotetext{
"KPK Harap Hakim Pikirkan Pentingnya Pencabutan Hak Politik Koruptor", https://nasional.kompas.com/read/2017/01/06/09374441/kpk.harap.hakim.pikirkan.pentingnya.pencabuta n.hak.politik.koruptor, diakses tanggal 2 Februari 2019.
} 
Di sisi yang lain, tidak sedikit juga para pelaku tindak pidana korupsi yang sudah di jatuhi pencabutan hak politik, ${ }^{2}$ seperti Gubernur Nonaktif Sulawesi Tenggara Nur Alam, Gubernur Nonaktif Bengkulu Ridwan Mukti, Mantan Ketua Dewan Perwakilan Daerah (DPD) Republik Indonesia Irman Gusman dan lainlainnya. Jika dilihat data dari Komisi Pemberantasan Korupsi (KPK) ${ }^{3}$ yang disampaikan lewat media menyebutkan, bahwa ada 26 pelaku tindak pidana korupsi yang sudah dicabut hak politiknya sepanjang 2013-2017. Meskipun sebenarnya ini masih sedikit jika dibandingkan dengan jumlah banyaknya kasus yang diproses oleh KPK

Jika dilihat sedikit mendalam sanksi pidana yang di jatuhkan terhadap pelaku tindak pidana korupsi bukan saja merugikan dari aspek hukum, dimana sangat mencederai nilai rasa keadilan, tetapi juga aspek sosiologis, dimana secara tidak langsung menciptakan kembali peluang terjadinya kerugian negara dengan waktu yang relatif singkat oleh pelaku yang sama, dan juga mempersempit ruang dan peluang generasi bangsa untuk ikut dalam kontestasi mewujudkan kesejahteraan sosial melalui good governance. Artinya sanksi pidana yang diberikan terhadap pelaku tindak pidana korupsi tidak memberikan efek jera, apalagi pencegahan. Justru sebaliknya secara tidak langsung memberikan peluang atau kesempatan dalam tempo yang relatif singkat untuk menjadi residivis pelaku tindak pidana korupsi. Padahal hukum pidana dengan konsep pemidanaanya dengan tegas dan jelas memberikan fungsi disamping efek jera juga pencegahan terjadinya sebuah tindak pidana.

Pada Pasal 10 Kitab Undang-Undang Hukum Pidana (KUHP), pencabutan hak dipilih dan memilih atau yang bahasa umumnya disebut sebagai hak politik merupakan sanksi pidana tambahan yang dapat di jatuhkan sebagai pidana tambahan terhadap pelaku tindak pidana. Oleh karena itu, pencabutan hak dipilih merupakan satu-satunya sanksi pidana yang efektif, yang dapat memberikan bukan saja efek jera melainkan pencegahan. Agar tidak terulang kembali tindak

\footnotetext{
"Terbukti Korupsi, Ini 8 Pejabat Yang dicabut Hak Politiknya", https:// news.okezone.com/read/2018/03/30/337/1879995/terbukti-korupsi-ini-8-pejabat-yang-dicabut-hakpolitiknya, diakses tanggal 2 Februari 2019.

3 “KPK: Hak Politik Dicabut 2013-2017”, https://nasional.kompas.com/read/2018/09/18/13252541 /kpk-hak-politik-26-koruptor-dicabut-sepanjang-2013-2017, diakses tanggal 2 Februari 2018.
} 
pidana korupsi khususnya terhadap pelaku yang sama dalam tempo waktu yang relatif singkat. Namun, yang menjadi persoalan khususnya didalam penegakan hukum sanksi pencabutan hak dipilih tidak menjadi primadona atau standar didalam penegakan hukum tindak pidana korupsi. Bukan karena pidana tambahan bersifat fakultatif. Namun, disebabkan adanya perbedaan pandangan di kalangan penegak hukum terkait pencabutan hak di pilih. Hak dipilih dianggap merupakan hak yang melekat pada manusia yang tidak dapat dikurangi. Sehingga ketika hak itu dicabut merupakan pelanggaran hak asasi manusia.

Padahal sejatinya, hukum pidana sudah mengatur dengan jelas dan tegas begitu juga dengan Undang-Undang Nomor 39 Tahun 1999 tentang Hak Asasi Manusia memberikan legitimasi pengurangan atau pencabutan hak. Artinya pencabutan hak dipilih sesungguhnya adalah konstitusional dan bukan pelanggaran hak asasi, dimana hak itu sesungguhnya tetap di lekatkan pada pemiliknya tanpa dikurangi sediktpun. Hak itu dapat dicabut atau dikurangi karena alasan yang diatur oleh Undang-Undang. Oleh karena itu, penjatuhan sanksi pencabutan hak dipilih seyogyanya menjadi primadona dan sebuah keharusan di kalangan aparat penegak hukum terhadap para pelaku tindak pidana korupsi sebagai upaya dalam pemberantasan dan pencegahan tindak pidana korupsi di Indonesia demi mewujudkan keadilan sosial dan kesejahteraan sosial melalui good governance.

\section{Rumusan Masalah}

Berdasarkan paparan di atas, maka pokok-pokok permasalahan yang diangkat dalam tulisan ini adalah sebagai berikut. Pertama, bagaimana pencabutan hak dipilih dalam perspektif peraturan perundang undangan? Kedua, bagaimana efektivitas pencabutan hak dipilih dalam pemberantasan korupsi?

\section{Tujuan Penelitian}

Adapun tujuan dari penulisan artikel ini, pertama, mengkaji hukum dan efektivitas pencabutan hak dipilih terhadap koruptor dalam pemberantasan tindak pidana korupsi bertujuan untuk menganalisis perspektif hukum positif; dan kedua, mengkaji efektifitas penjatuhan sanksi pencabutan hak dipilih dalam pemberantasan tindak pidana korupsi. 


\section{Metode Penelitian}

Artikel ini menggunakan metode penelitian hukum normatif yang meneliti norma hukum, sinkronisasi hukum, asas hukum, dan sampai pada tujuan hukum itu sendiri serta efektif atau tidaknya hukum itu. Artikel ini menganalisis norma hukum dan efektifitas penjatuhan sanksi pencabutan hak dipilih terhadap pelaku koruptor dalam pemberantasan tindak pidana korupsi menggunakan dua pendekatan: pertama, pendekatan peraturan perundang-undangan, yaitu melihat semua peraturan perundang-undangan yang ada terkait dengan pencabutan hak dipilih. Kedua, adalah pendekatan konseptual, yaitu mendeskripsikan bagaimana efektivitas dari penjatuhan pencabutan hak dipilih terhadap pelaku koruptor dalam pemberantasan tindak pidana korupsi. Bahan hukum yang digunakan berupa bahan hukum primer, yaitu Undang-Undang Dasar 1945, Kitab UndangUndang Hukum Pidana dan Undang-Undang Nomor 39 Tahun 1999 tentang Hak Asasi Manusia, Undang-Undang Nomor 31 Tahun 1999 sebagaima telah diubah menjadi Undang-Undang Nomor 20 Tahun 2001 tentang Pemberantasan Tindak Pidana Korupsi dan Putusan Mahkamah Konstitusi Nomor 14-17/PUU-V/2007. Sedangkan bahan hukum tersier, jurnal, buku, doktrin dan lainnya. Kemudian di telaah dan disajikan dalam bentuk pendeskripsian sehingga analisis yang digunakan adalah kualitatif dengan menekankan pada penalaran hingga pada penarikan kesimpulan.

\section{Hasil Penelitian dan Pembahasan}

Dalam teori positivisme hukum, konsep norma adalah sesuatu yang seharusnya ada atau seharusnya terjadi, khususnya manusia seharusnya berperilaku dengan cara tertentu. ${ }^{4}$ Hart ${ }^{5}$ mengatakan hukum seharusnya konkret maka harus ada yang menuliskan. Hart ${ }^{6}$ membagi dua bagian hukum, pertama, primary rules yaitu aturan-aturan hukum yang secara langsung memberikan hak-

\footnotetext{
${ }^{4}$ Hans Kelsen, Teori Hukum Murni: Dasar-Dasar Ilmu Hukum Normatif, Nusamedia \& Nuansa, Bandung, 2007, hlm. 4.

${ }^{5}$ FX. Adji Samekto, "Menggugat Relasi Filsafat Postivisme Dengan Ajaran Hukum Doktrinal", Jurnal Dinamika Hukum, Vol. 12, No. 1, hlm. 80.

${ }^{6}$ Ibid, hlm. 81.
} 
hak dan kewajiban kepada tiap-tiap individu. Kedua, secondary rules yaitu aturanaturan hukum yang memberikan hak dan kewajiban kepada penguasa. Artinya yang dapat di kategorikan sebuah hukum adalah sesuatu yang ada, dengan kata lain apa yang tertulis. Dalam ajaran filsafat positivisme hukum sebagaimana yang dikemukakan Hart sebelumnya, hukum atau peraturan perundang-undangan dapat menjadikan seseorang terhukum atau kehilangan hak serta memperoleh hak. Hukum positif atau peraturan perundang-undangan merupakan hukum yang dicita-citakan, sehingga tidak ada alasan untuk tidak menegakkan hukum oleh pemerintah dan juga aparat penegak hukum khususnya pengadilan. Hukum positif adalah hukum yang tertulis, yang mengikat seluruh lapisan masyarakat tanpa terkecuali. Konstitusional atau tidak pencabutan hak dipilih dapat dilihat berlandaskan teori positivisme hukum.

Selanjutnya efektivitas merupakan pengaruh keberhasilan atau kemanjuran. Menurut The Liang Gie,7 efektivitas itu adalah keadaan atau kemampuan kerja yang dilaksanakan oleh manusia untuk memberikan guna yang diharapkan. Sedangkan menurut Komaruddin ${ }^{8}$ efektivitas adalah suatu keadaan yang menunjukkan tingkat keberhasilan kegiatan manajemen dalam mencapai tujuan yang telah ditetapkan terlebih dahulu. Antohony Allot ${ }^{9}$ mengemukakan, teori efektivitas hukum dengan mengatakan hukum yang efektif adalah jika tujuan keberadaan dan penerapannya dapat mencegah perbuatan-perbuatan yang tidak di inginkan dapat menghilangkan kekacauan. Dalam konteks pencabutan hak dipilih terhadap koruptor secara konsep dapat dilihat efektif atau tidaknya sanksi tersebut di dalam pemberantasan korupsi menggunakan teori efektivitas hukum. Kemudian dikombinasikan dengan tujuan pemidanaan yaitu teori relatif. Tujuan pemidanaan dalam pandangan teori relatif adalah melindungi masyarakat atau mencegah terjadinya kejahatan. ${ }^{10}$ Diancamkannya suatu pidana untuk menakuti calon penjahat atau penjahat yang bersangkutan, menjamin ketertiban hukum atau pencegahan umum.

${ }^{7}$ Azhar Kasim, Pengukuran Efektifitas Dalam Organisasi, Penerbit Fakultas Ekonomi Universitas Indonesia, Jakarta, 2000, hlm. 23.

8 Ibid

${ }^{9}$ Salim H.S., Erlis Septiana Burbani, Penerapan Teori Hukum Pada Tesis dan Desertasi, Rajawali Pers, Jakarta, 2013, hlm. 303.

${ }_{10}$ Sianturi, Asas-Asas Hukum Pidana Di Indonesia Dan Penerapannya, Alumni Ahaem-Petehaem Jakarta, 1996, hlm. 60 . 


\section{Pencabutan Hak dipilih Menurut Hukum Positif}

Dalam hukum positif atau peraturan perundang-undangan setidaknya ada dua aturan hukum secara umum yang bersinggungan dengan pencabutan hak dipilih:

\section{Perspektif Hukum Pidana}

Macam-macam sanksi pidana di dalam Kitab Undang-Undang Hukum Pidana (KUHP) terdapat pada Pasal 10 secara umum terbagi dua, pidana pokok dan pidana tambahan. Di dalam doktrin hukum pidana mengatakan ubi non est principalis non potest esse accessorius, di mana tidak ada hal yang pokok, maka tidak mungkin ada tambahan. ${ }^{11}$ Artinya penjatuhan sanksi pidana tambahan harus di barengi oleh pidana pokok. Namun tidak sebaliknya pidana pokok boleh di jatuhkan tanpa dibarengi pidana tambahan.

Pencabutan hak dipilih ditempatkan pada pidana tambahan yang merupakan bagian dari pencabutan beberapa hak tertentu. Pencabutan hak tertentu, termasuk pencabutan hak dipilih, dapat dilakukan dengan menentukan waktu lamanya pencabutan hak tersebut sebagaimana yang diatur dalam Pasal 38 KUHP. Pertama pencabutan hak selama seumur hidup untuk terpidana dijatuhi pidana mati atau di hukum penjara seumur hidup. Kedua, pencabutan hak minimal 2 tahun dan maksimal 5 tahun lebih lama dari lamanya pidana penjara atau kurungan yang dijatuhkan untuk terpidana di jatuhi pidana penjara untuk waktu tertentu atau pidana kurungan. Ketiga, pencabutan hak minimal dua tahun dan maksimal lima tahun untuk terpidana yang di jatuhi pidana denda. Dan untuk mulai berlakunya pencabutan hak adalah pada hari putusan hakim dapat dijalankan.

Selanjutnya pencabutan hak memilih dan dipilih seiring perkembangannya dalam Putusan Mahkamah Konstitusi Nomor 14-17/PUU-V/2007 mengenai pengujian Pasal 58 huruf Undang-Undang Nomor 32 Tahun 2004 tentang Pemerintahan Daerah terhadap Undang Undang Dasar Republik Indonesia Tahun 1945 yang mengatur mengenai pencabutan hak dipilih. Pencabutan hak dipilih dapat dilakukan pada kriteria di samping tidak berlaku untuk kejahatan kealpaan

${ }^{11}$ Eddy O.S. Hiariej, Prinsip-Prinsip Hukum Pidana, Cahaya Atma Pustaka, Yogyakarta, 2018, hlm. 402. 
ringan (culpa levis) dan kejahatan karena alasan politik, dipersempit keberlakuannya hanya untuk jabatan publik yang dipilih (elected official). Artinya secara hukum positif pencabutan hak dipilih dapat dijatuhkan terhadap pelaku tindak pidana korupsi yang memiliki jabatan publik lewat pemilihan.

Disamping itu undang-undang tentang Pemberantasan Tindak Pidana Korupsi Nomor 31 Tahun 1999 sebagaimana yang telah diubah menjadi UndangUndang Nomor 20 Tahun 2001 (UU Tipikor) pada Pasal 17 menyebutkan: "selain dapat dijatuhi pidana sebagaimana dimaksud dalam Pasal 2, Pasal 3, Pasal 5 sampai dengan Pasal 14 terdakwa dapat dijatuhi tambahan sebagaimana dimaksud dalam Kitab Undang-Undang Hukum Pidana." Bahkan pada Pasal 18 ayat (1) menyebutkan adanya sanksi pidana tambahan bahkan di luar dari KUHP ada beberapa pidana tambahan; selain pidana tambahan sebagaimana dimaksud dalam Kitab Undang-Undang Hukum Pidana, sebagai pidana tambahan adalah:

a. Perampasan barang bergerak yang berwujud atau yang tidak berwujud atau barang tidak bergerak yang digunakan untuk atau yang diperoleh dari tindak pidana korupsi, termasuk perusahaan milik terpidana di mana tindak pidana korupsi dilakukan, begitu pula dari barang yang menggantikan barang-barang tersebut.

b. Penggantian uang pengganti yang jumlahnya sebanyak-banyaknya sama dengan harta benda yang diperoleh dari tindak pidana korupsi.

c. Penutupan seluruh atau sebagian perusahaan untuk waktu paling lama 1 (satu) tahun.

d. Pencabutan seluruh atau sebagian hak-hak tertentu atau penghapusan seluruh atau sebagian keuntungan tertentu, yang telah atau dapat diberikan oleh Pemerintah kepada terpidana.

Jika dilihat secara normatif, artinya pencabutan hak dipilih dapat dijatuhkan terhadap pelaku tindak pidana, karena KUHP dan UU Tipikor sendiri dengan tegas menyebutkan pencabutan hak dipilih bagian dari sanksi pidana tambahan. Dalam konteks tindak pidana korupsi, penjatuhan sanksi pencabutan hak dipilih adalah sangat tepat. Mengingat pelaku tindak pidana korupsi adalah lebih banyak pemegang jabatan publik. Sehingga memiliki korelasi antara sanksi yang di berikan sebagai konsekuensi dari perbuatan pidananya itu sendiri, yaitu tindak pidana korupsi. Meskipun pada umumnya seluruh sektor sudah pernah dan memiliki potensi melakukan tindak pidana korupsi. 


\section{Perspektif Hukum Hak Asasi Manusia}

Hak asasi manusia merupakan hak yang dimiliki atau yang melekat pada manusia disebabkan kemanusiaannya atau dikarenakan ia manusia. Suatu negara dapat disebut sebagai negara hukum manakala menjamin dan melindungi hak asasi manusia warga negaranya serta menjamin keadilan untuk seluruh rakyatnya dalam setiap dimensi kehidupan. ${ }^{12}$ Dalam konteks hak asasi manusia, negara menjadi subjek hukum utama, karena negara merupkan entitas utama yang bertanggung jawab melindungi, menegakkan dan memajukan hak asasi manusia, setidaknya untuk warga negaranya masing-masing. ${ }^{13}$

Indonesia di dalam konstitusinya dapat dilihat secara jelas mengakomodir persoalan hak asasi manusia, ini merupakan bagian daripada bukti upaya yang dilakukan untuk melindungi dan memajukan hak asasi manusia merupakan hal yang sangat strategis sehingga memerlukan perhatian dari seluruh elemen bangsa. Yang kamudian secara spesifik diakomodir dan diatur di dalam Undang-Undang Nomor 39 Tahun 1999 tentang Hak Asasi Manusia. Pasal 43 Undang-Undang Nomor 39 Tahun 1999 tentang Hak Asasi Manusia menyebutkan: setiap warga negara berhak untuk dipilih dan memilih dalam pemilihan umum berdasarkan persamaan hak melalui pemungutan suara yang berlangsung, umum, bebas, rahasia, jujur, dan adil sesuai dengan ketentuan peraturan perundang-undangan. Dengan demikian, secara tegas disebutkan dan pada prinsipnya hak dipilih maupun memilih bagian dari hak asasi manusia.

Selanjutnya pada Pasal 73 Undang-Undang Nomor 39 Tahun 1999 tentang Hak Asasi Manusia menyebutkan: "hak dan kebebasan yang diatur dalam Undang-Undang ini hanya dapat dibatasi oleh dan berdasarkan undang-undang, semata-mata untuk menjamin pengakuan dan penghormatan terhadap hak asasi manusia serta kebebasan dasar orang lain, kesusilaan, ketertiban umum dan kepentingan negara." Artinya hak seseorang dapat di batasi oleh dan berdasarkan undang-undang. Jika dikaitan dengan pencabutan hak dipilih terhadap pelaku

${ }^{12}$ Suparman Marzuki, To Promote: Membaca Perkembangan Wacana Hak. Asasi Manusia di Indonesia, PUSHAM UII, Yogyakarta, 2012, hlm. 77.

${ }_{13}$ Rhona K.M. Smith, dkk., Hukum Hak. Asasi Manusia, PUSHAM UII, Yogyakarta, 2008, hlm. 53. 
tindak pidana korupsi, undang-undang tentang Hak Asasi Manusia sangat tegas dan jelas membolehkan pembatasan hak. Pencabutan hak dipilih sama halnya dengan pembatasan hak, sebab pencabutan hak dipilih memiliki batas waktu. Dan ini bukan merupakan pelanggaran hak asasi.

Adalah tidak tepat ketika terhadap pelaku yang terbukti melakukan tindak pidana korupsi dijatuhi pencabutan hak dipilih di anggap sebagai pelanggaran hak asasi manusia. Jika dilihat kembali Pasal 73 Nomor 39 Tahun 1999 tentang Hak Asasi Manusia, negara dalam hal ini melindungi, menegakkan dan memajukan hak asasi. Lewat pengadilan dengan mencabut hak dipilih seorang terpidana koruptor, negara melindungi dan menegakkan serta memajukan hak asasi tiap-tiap individu yang di rampas haknya oleh koruptor untuk menjaga kepentingan umum dan kepentingan negara. Justru pelaku tindak pidana korupsi adalah pelanggar hak asasi yang tidak harus dilindungi dengan dalih perlindungan hak asasi. Hak untuk hidup layak, untuk mendapatkan pelayanan publik dengan baik dan hak-hak dasar lainnya tidak terpenuhi disebabkan banyaknya uang negara yang di rampok oleh para koruptor yang seharusnya bisa digunakan untuk memenuhi hak dasar warga negara atau masyarakat, justru ditarik dan mengalir dengan deras ke kantong-kantong pribadi. Koruptor mencederai kesejahteraan rakyat, khususnya rakyat kecil.

\section{Efektifitas Pencabutan Hak Dipilih Dalam Pemberantasan Korupsi.}

Sebelum lebih jauh membahas pencabutan hak dipilih, ada baiknya dijelaskan sedikit mengenai alasan pemilihan frasa pencabutan hak dipilih, bukan menggunakan frasa pencabutan hak politik. Pada dasarnya pencabutan hak dipilih bagian dari pencabutan hak-hak tertentu dalam hukum pidana. Sebagian dari pencabutan hak politik dari hak untuk memilih dan hak untuk dipilih. Namun, jika dilihat di dalam hukum positif, pada dasarnya pengertian hak politik tidak di temukan. ${ }^{14}$ Baik itu di dalam Kitab Undang-Undang Hukum Pidana, UndangUndang tentang Hak Asasi Manusia, Undang-Undang tentang Pemberantasan Tindak Pidana, maupun di dalam peraturan perundang-undangan lainnya.

${ }^{14}$ Haliva Muharosa, "Tinjauan Yuridis Terhadap Pencabutan Hak Politik Bagi Terpidana Korupsi Di Indonesia", Jurnal JOM Fakultas Hukum, Vol. 3 No. 1, Februari 2016, hlm. 10. 
Cakupan hak politik sesungguhnya sangat luas. Jimly Asshidhiqie ${ }^{15}$ menyebutkan kelompok hak-hak politik yang dijamin dalam Undang-Undang Dasar Republik Indonesia meliputi hak untuk berserikat, berkumpul, dan menyatakan pendapat, hak untuk memilih dan dipilih dalam rangka lembaga perwakilan rakyat, serta hak untuk dapat diangkat dalam kedudukan jabatan publik. Frasa yang digunakan dalam undang-undang adalah hak memilih dan hak dipilih. Artinya keduanya dapat dipisah dan bukan satu kesatuan. Begitu juga dalam prakteknya pada putusan pengadilan, pencabutan hak dipilih tidak otomatis tercabut hak memilih begitu juga sebaliknya pencabutan hak memilih tidak otomatis tercabut hak dipilih. Artinya keduanya adalah berdiri sendiri. Dengan demikian penggunaan frasa hak politik adalah terlalu umum.

Pada dasarnya sebagaimana yang disebutkan sebelumnya hak memilih dan hak dipilih bukanlah satu kesatuan yang tidak terpisahkan. Pada konteks pemilihan diluar pemahaman hukum positif, dalam sistem demokrasi hak memilih adalah hak yang tidak dapat dikurangi apalagi dicabut. Tiap-tiap individu memiliki hak untuk memilih siapa yang terbaik untuk dijadikan pemimpin yang akan memegang sebuah jabatan tertentu untuk menjalankan kepemimpinanya ke arah yang lebih baik, termasuk dirinya sendiri di dalamnya yang akan dipimpin. Hak untuk memilih tidak memiliki tanggung jawab moral atas apa yang dipilihnya, seperti memilih calon kepala daerah ataupun anggota lesgislatif.

Berbeda dengan hak untuk dipilih yang memiliki tanggung jawab penuh atas hasil keterpilihan. Terpilih menjadi pemimmpin utnuk menduduki suatu jabatan tertentu sesungguhnya memiliki tanggung jawab penuh atas jabatan yang diperolehnya. Tanggung jawab itu terletak pada berjalan atau tidak tugas dan fungsi atas jabatannya sesuai dengan apa yang diharapkan oleh pemilihnya. Pada prakteknya juga, orang yang terdaftar sebagai yang dipilih pasti dibarengi dengan hak memilih namun bukan sebaliknya. Orang yang memiliki hak untuk memilih belum tentu dibarengi dengan hak untuk dipilih. Dengan demikian pencabutan hak dipilih lebih tepat daripada pencabutan hak milih. Meskipun secara normatif,

${ }^{15}$ Jimly Asshiddiqie, Konstitusi Dan Konstitusionalisme Indonesia, Sinar Grafika, Jakarta, 2010, hlm. 90. 
undang undang khususnya hukum pidana memberikan legitimasi untuk dilakukan pencabutan keduanya kepada pelaku pelanggar hukum pidana.

\section{Urgensi dan Efektivitas Pencabutan Hak Dipilih Terhadap Koruptor dalam Pemberantasan Korupsi}

Sejak lahirnya reformasi, menyelesaikan korupsi menjadi tugas utama. Adalah mustahil mereformasi sebuah negara jika korupsi masih merajalela. Merupakan sebuah impian belaka untuk memberantas kemiskinan meningkatkan kualitas pendidikan dan pelayanan kesehatan jika korupsi masi tumbuh subur. Sebab korupsi adalah sumber bencana dan kejahatan (the roots of all evils). ${ }^{16}$ Sampai dengan sekarang masuk tahun 2019 korupsi di Indonesia masih saja merajalela. Korupsi menjadi faktor penghambat pembangunan ekonomi, politik, sosial dan budaya.

Korupsi di Indonesia dapat dikatakan sudah stadium 4, sebab semua sektor baik itu eksekutif, legislatif dan yudikatif sudah pernah terjerat kasus tindak pidana korupsi. Bahkan isu korupsi di jadikan sebagai bahan kampanye politik untuk melakukan perlawanan atau pembasmian terhadap korupsi. Dari waktu ke waktu pergantian presiden terus berlangsung, kampanye maupun kebijakan yang dilakukan oleh pemerintah untuk melawan korupsi terus digaungkan. Mulai dari membentuk dan merevisi Undang-Undang tentang Tindak Pidana Korupsi, sampai dengan yang terakhir didirikannya KPK sebagai lembaga independen yang didirikan khusus untuk menangani kasus tindak pidana korupsi. Masyarakat dari berbagai komunitas juga ikut mengambil peran dan menyuarakan perlawanan terhadap korupsi. Mulai dari melakukan pendidikan yang bertemakan Sekolah Anti Korupsi. Namun tetap saja korupsi masih merajalela.

Ada dua faktor yang menyebabkan terjadinya kroupsi, yaitu faktor internal dan faktor eksternal. ${ }^{17}$ Faktor internal ${ }^{18}$ meliputi; sifat atau kepribadian yang rakus, kurangnya ahlak dan moral, iman yang lemah, penghasilan tidak mencukupi, kebutuhan hidup, menuruti gaya hidup dan tidak mau sengsara dalam bekerja.

16 Aziz Syamsuddin, Tindak Pidana Khusus, Sinar Grafika, Jakarta, 2016, hlm. 175.

${ }^{17}$ Chatrina Darul Rosikah dan Dessy Marliani Listianingsih, Pendidikan Anti Korupsi: Kajian Antikorupsi Teori dan Praktik, Sinar Grafika, Jakarta, 2016, hlm. 7.

${ }^{18}$ Ibid., hlm.7. 
Sedangkan faktor eksternal ${ }^{19}$ meliputi; faktor ekonomi, faktor organisasi, faktor politik, faktor perilaku masyarakat dan faktor hukum.

Sejatinya korupsi adalah sebagai kejahatan luar biasa (extraordinary crime). Dalam dunia internasional, pengakuan terhadap korupsi merupakan masalah yang sangat kompleks, memiliki sifat yang sitemik dan meluas. ${ }^{20}$ Perserikatan Bangsa Bangsa (PBB) mendefenisikan korupsi sebagai missus of (public) power for private gain. Menurut CICP korupsi memiliki dimensi perbuatan yang luas, meliputi suap, penggelapan, penipuan, pemeresan yang berkaitan dengan jabatan, penyalahgunaan kekuasaan, pemamfaatan kedudukan seseorang dalam aktivitas bisnis untuk kepentingan perorangan yang bersifat ilegal, nepostisme, komisi illegal yang di terima oleh pejabat publik dan kontribusi uang secara illegal untuk partai politik. Di samping itu, korupsi juga sebagai masalah dunia yang bersifat kejahatan lintas negara.

Jika dilihat dari parakteknya tindak pidana korupsi cenderung dan sering diidentikkan dengan cara penyalahgunaan wewenang atau kekuasaan demi mendapatkan keuntungan secara pribadi. Melihat realitas dan fakta yang ada para pelaku tindak pidana korupsi yang sudah diproses dan divonis oleh pengadilan umumnya adalah di isi oleh para elite penguasa atau yang memegang sebuah jabatan atau kekuasaan baik di eksekutif, yudikatif dan legislatif. Mereka mempengaruhi pihak lain yang berada di bawah kekuasaannya atas dasar kekuasaan dan kedudukannya dengan suatu kebijakan. ${ }^{21}$ Yang paling ironis adalah mereka yang menduduki sebuah jabatan diperoleh dari mandat rakyat lewat kontestasi pemilihan. Namun, menggunakan jabatan tersebut untuk kepentingan dirinya pribadi maupun kelompok.

Meskipun penegakan hukum sudah dilakukan bagi mereka pelaku tindak pidana korupsi dan setelah menjalani hukuman tetap saja mereka tidak memiliki

${ }^{19}$ Ibid., hlm.8.

20 "Tindak Pidana Korupsi Sebagai Extraordinary Crime", https://www.researchgate.net/publication/ 322789917_TINDAK_PIDANA_KORUPSI_SEBAGAI_EXT RAORDINARY_CRIME, diakses tanggal 10 Februari 2019.

21 Oksidelfa Yanto, "Efektifitas Putusan Pemidanaan Maksimal Bagi Pelaku Tindak Pidana Korupsi Dalam Rangka Pengentasan Kemiskinan”, Syaih Kuala Law Jurnal, Vol. 1 No. 2, 2017, hlm. 22. 
rasa malu untuk tetap maju mengambil mandat dari rakyat untuk menduduki suatu jabatan dalam kontestasi pemilu ataupun menerima sebuah jabatan yang bukan lewat kontetasi pemilu. Memang hal ini bukanlah suatu yang terlarang oleh hukum, namun secara etika dan tanggung jawab moral mereka sudah melakukan pengkhianatan terhadap sebuah amanah sebelumnya.

Dengan demikian, penjatuhan pidana tambahan yaitu pencabutan hak dipilih menjadi hal yang penting untuk dilakukan terhadap pelaku tindak pidana korupsi. Jika dilihat secara praktik korelasi perbutan pidana yang dilakulan oleh koruptor yang cenderung menyalahgunakan kewenangan ataupun jabatan dengan pencabutan hak dipilih adalah sangatlah relevan, terlepas apakah jabatan itu di peroleh melalui pemilihan umum ataupun tidak. Hanya saja Putusan Mahkamah Konstitusi Nomor 14-17/PUU-V/2007 mempersempit ruang dijatuhkannya pencabutan hak dipilih. Sebab pemidanaan bukan saja berfungsi untuk memberikan efek jera tetapi juga untuk melakukan pencegahan. Sebagaimana tujuan pemidanaan yang dikemukakan oleh ajaran teori relatif 22 bahwa pemidanaan dijatuhkan berdasarkan maksud dan tujuan hukuman, yaitu memperbaiki ketidak puasan masyarakat sebagai akibat dari kejahatan itu. Tujuan hukuman harus dipandang secar ideal. Selain itu. Tujuan hukuman adalah mencegah kejahatan. ${ }^{23}$

Pencabutan hak dipilih terhadap pelaku tindak pidana korupsi disamping memberikan efek jera juga mencegah terjadinya kejahatan yang sama dalam waktu yang relatif singkat. Tidak dapat dibayangkan jika seorang mantan terpidana tindak pidana korupsi kembali menduduki sebuah jabatan dan mengulang kembali kejahatan yang sama. Maka, sungguh besar kerugian negara dan dampaknya terhadap masyarakat. Jika dilihat dampak yang ditimbulkan oleh tindak pidana korupsi, setidaknya ada tiga alasan pokok dilakukannya pencabutan hak di pilih: 1) Korupsi menimbulkan kerugian keuangan negara; 2) Korupsi mematikan fungsi hukum atau peraturan perundang-undangan; 3) Korupsi menutup ruang dan peluang generasi bangsa ikut andil berkontribusi membangun negara lewat kekuasaan baik itu pada tingkat eksekutif, legislatif dan yudikatif.

22 Juhaya S. Praja, Teori Hukum dan Aplikasinya, Pustaka Setia, Bandung, 2014, hlm. 192.

${ }^{23}$ Ibid 
Ketiga dampak yang ditimbulkan oleh tindak pidana korupsi menjadi alasan kuat untuk dilakukannya pencabutan hak dipilih terhadap pelaku tindak pidana. Dampak-dampak tersebut mematikan seluruh sektor dan komponen kehidupan didalam sebuah negara. Ekomoni tidak berjalan dengan baik dan tidak merata, hukum diperjual belikan dan demokrasi hanya di isi dan dikuasai oleh orang-orang kapitalis atau pemilik modal. Pada dasarnya pencabutan hak dipilih terhadap pelaku tindak pidana tidak dapat memberikan jaminan untuk tidak terjadi korupsi. Namun setidaknya, pencabutan hak dipilih dapat memberikan daya pencegahan dalam tempo yang relatif lama terhadap pelaku yang sama. Juga efek jera dan pencegahan terhadap pelaku yang sama dan orang-orang yang hendak melakukan perbuatan tindak pidana korupsi.

Setelah melihat tiga alasan kuat yang menjadi dasar dilakukannya pencabutan hak dipilih terhadap pelaku tindak pidana korupsi. Secara konseptual, ada beberapa mamfaat yang dapat dicapai dalam pemberantasan tindak pidana korupsi: 1) Pencabutan hak dipilih mencegah terjadinya residivis pelaku tindak pidana korupsi; 2) Pencabutan hak dipilih dapat meminimalisir kerugian keuangan negara; 3) Hukum berjalan sesuai dengan yang di undangkan; 4) Pencabutan hak dipilih membuka ruang dan peluang kepada generasi bangsa berkontribusi membangun negara lewat kekuasaan baik itu pada tingkat eksekutif, legislatif dan yudikatif.

Efektivitas memiliki makna pengaruh keberhasilan atau kemanjuran. Keefektifan sebuah hukum tidak dapat dilepaskan dari karakterististik dari objek sasaran yang dipergunakan. ${ }^{24}$ Beberapa ahli mengemukakan pengertian efektifitas dengan konsep yang berbeda-beda, diantaranya The Liang Gie, ${ }^{25}$ mengemukakan efektifitas itu adalah keadaan atau kemampuan kerja yang dilaksanakan oleh manusia untuk memberikan guna yang diharapkan. Sedangkankan Komaruddin, ${ }^{26}$ mengemukakan bahwa efektifitas adalah suatu keadaan yang menunjukkan

${ }^{24}$ Barda Nawawi Arief, Kapita Selekta Hukum Pidana, Citra Aditya, Bandung, 2013, hlm. 67.

25 Azhar Kasim, Pengukuran Efektifitas Dalam Organisasi, Penerbit Fakultas Ekonomi Universitas Indonesia, Jakarta, 2000, hlm. 23.

${ }^{26}$ Ibid 
tingkat keberhasilan kegiatan manajemen dalam mencapai tujuan yang telah ditetapkan terlebih dahulu. Artinya jika dilihat dari dua pandangan efektifitas dari kedua ahli tersebut, efektifitas itu dapat diraih jika dilakukan dengan baik sesuai dengan apa yang direncanakan. Selanjutnya sebagaimana yang dikemukakan Anthony Allot, hukum yang efektif adalah jika tujuan keberadaan dan penerapannya dapat mencegah perbuatan-perbuatan yang tidak diinginkan dapat menghilangkan kekacauan.

Kaitannya dengan pencabutan hak dipilih adalah sebagaimana yang sudah di jelaskan sebelumnya salah satu dari tujuan pemidanaan itu adalah di samping memberikan efek jera juga untuk melakukan pencegahan. Maka dari itu pencabutan hak dipilih sudah menjadi keharusan bagi aparat penegak hukum khususnya hakim dijadikan sebagai sanksi primadona atau standar bagi para pelaku tindak pidana korupsi dalam rangka pemberantasan tindak pidana korupsi. Agar pemberantasan tindak pidana korupsi dengan menggunakan produk hukum yang ada dapat berjalan efektif.

\section{Penutup}

Berdasarkan pemaparan di atas, dapat disimpulkan, pertama, pencabutan hak dipilih dalam hukum posistif atau peraturan perundang-undangan setidaknya secara umum bersinggungan dengan 2 pokok peraturan perundang-undangan, yaitu hukum pidana dan tentang Hak Asasi Manusia. Dalam perspektif hukum memberikan legitimasi dilakukannya pencabutan hak dipilih bagi para pelaku tindak pidana sebagai bagian dari pidana tambahan pada sub pencabutan beberapa hak tertentu, yang kemudian dipertegas di dalam Undang-Undang tentang Pemberantasan Tindak Pidana Korupsi itu sendiri. Dan lama pencabutan hak dipilih harus memiliki jangka waktu. Sedangkan dalam perspektif UndangUndang tentang Hak Asasi Manusia, pembatasan hak dapat dilakukan asalkan berdasarkan undang-undang. Pencabutan hak dipilih bagian dari pembatasan hak sebab memiliki batas waktu. Artinya Undang-Undang tentang Pemberantasan Korupsi sinkron dengan Undang-Undang tentang Hak Asasi Manusia. Dan bukan merupakan pelanggaran Hak Asasi Manusia. 
Kedua, pencabutan hak dipilih terhadap pelaku tindak pidana korupsi di samping memberikan efek jera juga mencegah terjadinya kejahatan yang sama oleh pelaku yang sama dalam waktu yang relatif singkat. Tidak dapat dibayangkan jika seorang mantan terpidana tindak pidana korupsi kembali menduduki sebuah jabatan dan mengulang kembali kejahatan yang sama. Maka sungguh besar kerugian negara dan dampaknya terhadap masyarakat.

Penegakan hukum terhadap tindak pidana korupsi tidak dapat dilakukan dengan setengah-setengah. Menggunakan produk hukum yang ada secara total menjadi kemestian dalam upaya pemberantasan korupsi. Oleh karenanya, aparat penegak hukum khususnya hakim menjadikan pencabutan hak dipilih sebagai sanksi primadona atau standar dalam pemberantasan tindak pidana korupsi. Sehingga bukan saja memberikan efek jera, tetapi juga memberikan pencegahan dari pelaku yang sama dan kerugian negara dalam tempo yang relatif singkat. Dengan demikian, nilai keadilan yang ada didalam masyarakat dapat terwujud.

\section{Daftar Pustaka}

\section{Buku}

Chatrine, Darul Rosikah dan Dessy Marliani Listianingsih, Pendidikan Anti Korupsi: Kajian Antikorupsi Teori dan Praktik, Sinar Grafika, Jakarta, 2016.

H.S., Salim dan Erlis Septiana Burbani, Penerapan Teori Hukum Pada Tesis dan Desertasi, Rajawali Pers, Jakarta, 2013.

K.M., Smith dan Rhona, dkk., Hukum Hak Asasi Manusia, PUSHAM UII, Yogayakarta, 2008.

Kasim, Azhar, Pengukuran Efektifitas Dalam Organisasi, Penerbit Fakultas Ekonomi Universitas Indonesia, Jakarta, 2000.

Kelsen, Hans, Teori Hukum Murni: Dasar-Dasar Ilmu Hukum Normatif, Nusamedia \& Nuansa, Bandung, 2007.

Marzuki, Suparman, To Promote: Membaca Perkembangan Wacana Hak Asasi Manusia di Indonesia, PUSHAM UII, Yogyakarta, 2012.

Nawawi, Arief Barda, Kapita Selekta Hukum Pidana, Citra Aditya, Bandung, 2013.

O.S., Hiariej, dan Eddy, Prinsip-Prinsip Hukum Pidana, Cahaya Atma Pustaka, Yogyakarta, 2018.

Praja, Juhaya S., Teori Hukum dan Aplikasinya, Pustaka Setia, Bandung, 2014. 
Sianturi, Asas-Asas Hukum Pidana Di Indonesia Dan Penerapannya, Alumni AhaemPetehaem, Jakarta, 1996.

Syamsuddin, Aziz, Tindak Pidana Khusus, Sinar Grafika, Jakarta, 2016.

\section{Jurnal}

Muharosa, Haliva, “Tinjauan Yuridis Terhadap Pencabutan Hak Politik Bagi Terpidana Korupsi Di Indonesia", Jurnal JOM Fakultas Hukum, Vol. 3 No. 1, 2016.

Samekto, FX Adji, "Menggugat Relasi Filsafat Postivisme Dengan Ajaran Hukum Doktrinal" Jurnal Dinamika Hukum, Vol. 12 No. 1, 2012.

Yanto Oksidelfa, "Efektifitas Putusan Pemidanaan Maksimal Bagi Pelaku Tindak Pidana Korupsi Dalam Rangka Pengentasan Kemiskinan", Syaih Kuala Law Jurnal, Vol. 1 No. 2, 2017.

\section{Peraturan Perundang-Undangan}

Kitab Undang-Undang Hukum Pidana.

Putusan Mahkamah Konstitusi Nomor 14-17/PUU-V/2007.

Undang-Undang Nomor 20 Tahun 2001 tentang Perubahan atas Undang-Undang Nomor 31 Tahun 1999 tentang Pemberantasan Tindak Pidana Korupsi.

Undang-Undang Nomor 39 Tahun 1999 tentang Hak Asasi Manusia.

\section{Internet}

“KPK: Hak Politik Dicabut 2013-2017", https://nasional.kompas.com/read/ 2018/09/18/13252541/kpk-hak-politik-26-koruptor-dicabut-sepanjang2013-2017, diakses tanggal 2 Februari 2018.

"KPK Harap Hakim Pikirkan Pentingnya Pencabutan Hak Politik Koruptor", https:nasional.kompas.com/read/2017/01/06/09374441/kpk.harap.haki m.pikirkan.pentingnya.pencabutan.hak.politik.koruptor, diakses tanggal 2 Februari 2019.

"Tindak Pidana Korupsi Sebagai Extraordinary Crime", https://www.researchgate.net/publication/322789917_TINDAK_PIDAN A_KORUPSI_SEBAGAI_EXTRAORDINARY_CRIME, diakses tanggal 10 Februari 2019.

"Terbukti Korupsi, Ini 8 Pejabat Yang dicabut Hak Politiknya", https://news.okezone.com/read/2018/03/30/337/1879995/terbukti-korupsi-ini-8pejabat-yang-dicabut-hak-politiknya, diakses tanggal 2 Februari 2019. 